\title{
Biodegradation of dispersed oil in natural seawaters from Western Greenland and a Norwegian fjord
}

\author{
Odd G. Brakstad ${ }^{1}$ (1) - Emlyn J. Davies ${ }^{1} \cdot$ Deni Ribicic $^{2} \cdot$ Anika Winkler $^{3} \cdot$ Ute Brönner $^{1} \cdot$ Roman Netzer $^{1}$
}

Received: 20 December 2017 / Revised: 16 July 2018 / Accepted: 17 July 2018 / Published online: 25 July 2018

(c) The Author(s) 2018

\begin{abstract}
With increasing oil exploration, production and transportation in the Arctic, predictions of the fate of spilled oil become important, including oil compound biodegradation. The use of chemical dispersants may result in increased biodegradation due to the generation of dispersions consisting of small oil droplets, but only few studies have focused on biodegradation of chemically dispersed oil in Arctic seawater. In this study we compared oil biotransformation in Arctic and temperate seawaters collected from Western Greenland (Disko Bay, surface and from $80 \mathrm{~m}$ depth) and a Norwegian fjord (Trondheimsfjord, surface). A naphthenic oil, premixed with a dispersant, was dispersed in the seawaters from the different sources, and the dispersions incubated in low concentrations in a carousel system at $4-5{ }^{\circ} \mathrm{C}$ for up to 64 days. Targeted oil compounds ( $n$-alkanes, BTEX, naphthalenes and PAHs) were biotransformed in both Arctic and temperate seawaters, although the degradation was faster in the temperate seawater. In the Arctic seawater, transformation was faster in the surface than in the subsurface seawater. Calculations of biotransformation rates and half-lives of oil compound groups representing 70-80\% of fresh oils also showed significantly faster depletion in the temperate than the Arctic seawater. Microbial analyses revealed differences between the bacterial communities in the seawater sources during oil biodegradation. The results emphasized, that oil compounds are biodegraded in Arctic seawater, but degradation potential and rates may vary between seawaters from different sources.
\end{abstract}

Keywords Oil $\cdot$ Dispersants $\cdot$ Dispersibility $\cdot$ Biodegradation $\cdot$ Seawater

\section{Introduction}

The Arctic regions represent areas of interest for oil exploration and production. According to an assessment made by the U.S. Geological Survey, the estimated occurrence of undiscovered oil and gas north of the Arctic Circle may be as much as 90 billion barrels of oil and 1669 trillion

Electronic supplementary material The online version of this article (https://doi.org/10.1007/s00300-018-2380-8) contains supplementary material, which is available to authorized users.

Odd G. Brakstad

odd.brakstad@sintef.no

1 Department of Environment and New Resources, SINTEF Ocean, Brattørkaia 17C, 7010 Trondheim, Norway

2 Department of Cancer Research and Molecular Medicine, The Norwegian University of Science and Technology, 7491 Trondheim, Norway

3 Centre for Biotechnology (CeBiTec), Bielefeld University, 33501 Bielefeld, Germany cubic feet of natural gas, most of it in offshore areas (Bird et al. 2008). The Greenland basin alone is estimated to contain 17 billion barrels of oil and 138.000 billion cubic feet of natural gas, and several offshore exploration licences have been granted west of Greenland (Olsen and Hansen 2014). Reduced ice coverage in the Arctic may also result in increased transport activities. Despite strict governmental regulations, accidental releases of oil from exploration, production and transport may occur and cause impacts on the local marine environments in these vulnerable areas. Oil spilled to the marine environment undergoes a number of weathering processes like evaporation, water-in-oil (w/o) emulsification, dispersion, dissolution of small and charged compounds, and photo-oxidation (NRC 2003). Biodegradation is also an important weathering process and may result in complete mineralization of hydrocarbons. However, the rates and extents of the degradation depend strongly on a variety of factors involving oil characteristics and environmental conditions. Oil compounds may be degraded by a variety 
of marine microbes, including bacteria, fungi, and algae (Prince 2005). While hydrocarbon-degrading bacteria in temperate seawater usually include members of the classes Alphaproteobacteria and Gammaproteobacteria, oil-polluted Arctic seawater and marine ice often become enriched by Gammaproteobacteria (Bowman and McCuaig 2003; Yakimov et al. 2004; Deppe et al. 2005; Gerdes et al. 2005; Brakstad et al. 2008; Bagi et al. 2014; McFarlin et al. 2014a; Garneau et al. 2016). In particular, the Exxon Valdez grounding in Prince Willam Sound in 1989 drew public attention to oil biodegradation of oil discharged in the Arctic, and bioremediation was used as a secondary treatment of stranded oil in the Arctic (Bragg et al. 1994).

Oil biodegradation is mainly associated with the dissolved and dispersed fractions of the oil. Small oil-droplet dispersions generate large surfaces which hydrocarbonoclastic bacteria may attach to, and several studies have shown that the use of oil spill dispersants may stimulate oil biodegradation (Siron et al. 1995; Venosa and Holder 2007; Bælum et al. 2012; Prince et al. 2013; Brakstad et al. 2014; McFarlin et al. 2014b; Techtmann et al. 2017). By encouraging the formation of small oil droplets, dispersants increase the surface-to-volume ratio of the oil and enhance oil biodegradation by creating larger oil surfaces for microbial attachment, but also dissolution of soluble compounds may be increased compared to oil emulsions. Efficient use of oil spill dispersants typically results in oil-droplet sizes of 10-20 $\mu \mathrm{m}$ diameter at breaking wave conditions (Brakstad et al. 2014). Some laboratory studies have also indicated negligible or uncertain effects of dispersants on oil compound biodegradation rates (Swannell and Daniel 1999; Lindstrom and Braddock 2002; Macnaughton et al. 2003), or even suggested that dispersants may suppress the activity of oil-degrading microbes (Kleindienst et al. 2015). However, these studies have often either been performed with very high oil concentrations, or dispersed oil has not been used. Once the oil is chemically dispersed, rapid dilution will occur in the water column. Environmental concentrations of dispersed oil over the period of biodegradation is expected to be below $1 \mathrm{mg} \mathrm{L}^{-1}$ (Lee et al. 2013). It has also been argued that the use of dispersants may be of advantage in the Arctic, since the chemicals can be applied by plane and are therefore less logistically challenging than mechanical treatment (Lewis and Prince 2018).

Cold seawater affects several physical processes. Lower temperatures will increase the oil viscosity. Evaporation will be also reduced, resulting in temporary higher concentrations of volatile compounds in the seawater (e.g. BTEX). For wax-rich oils with high pour points, evaporation, dissolution, and dispersion may be reduced in cold seawater. Precipitated wax may build a matrix which limits the internal mixing of the oil and acts as a diffusion barrier between the oil and the water.
In order to predict the fate of spilled oil in the marine environment, three-dimensional and dynamic oil spill models like OSCAR have been developed (Reed et al. 1995, 2000). These models include descriptions of the physical environment and the physical-chemical fate processes of the spilled oil. The strength of such multi-component models is that the contribution of the various fate processes can be estimated by mass balance calculations (Reed et al. 1995). Biodegradation has been included in the OSCAR model as part of the fate predictions of spilled oil, using biotransformation rates of 25 oil compound groups expecting to represent approximately $70-80 \%$ of the oil (Reed et al. 2000; Pasquini and Bueno 2007). The biodegradation rates have been obtained from laboratory studies conducted at $13{ }^{\circ} \mathrm{C}$ in natural temperate seawater (Brakstad and Faksness 2000). Temperature calibration of the biotransformation rates are currently performed by a $Q_{10}$ approach $\left(Q_{10}=2\right)$ (Bagi et al. 2013).

While numerous oil/hydrocarbon biodegradation studies have been performed with oil in seawater from temperate regions, fewer studies have been performed in cold Arctic or Antarctic seawater (e.g. Delille et al. 1998a, b, 2009; Bagi et al. 2014; McFarlin et al. 2014b; Kristensen et al. 2015; Scheibye et al. 2017). In this study, we compared biodegradation of small oil-droplet dispersions at low temperature, using natural non-amended seawater from Western Greenland (Disko Bay) and temperate seawater from a Norwegian fjord acclimated to low temperature. The objective of the study was to investigate if biodegradation of oil compounds in dispersed oil differed in the two seawater sources at similar experimental conditions. By this study, we aimed to obtain data to evaluate if biodegradation as input parameter in oil spill models like OSCAR should be generated as site-specific data for predictions of the fate of oil spills in Arctic seawater.

\section{Materials and methods}

\section{Seawater sampling and measurements}

Arctic seawater from Western Greenland was collected on 11. September 2016 in Disko Bay (DB), close to the Arctic Station in Qeqertarsuaq, a small town on Disko Island $\left(69^{\circ} 15^{\prime} \mathrm{N}, 53^{\circ} 34^{\prime} \mathrm{W}\right)$, see map in Supplementary Material (Online Resource 1). Vertical profiles of temperatures, salinities and densities were measured by a CTD (see Supplementary Material, Online Resource 2). Seawater was collected in a Niskin bottle sampler (10 L volume). Volumes of $60 \mathrm{~L}$ were collected from near the surface $(2.5 \mathrm{~m}$ depth) and $40 \mathrm{~L}$ from $80 \mathrm{~m}$ depth. Seawater temperatures were $5{ }^{\circ} \mathrm{C}$ in the surface and $2{ }^{\circ} \mathrm{C}$ in the sub-surface seawater. The seawater samples were transported in $19 \mathrm{~L}$ ( 5 gallon) 
Teflon (Polytetrafluoreten) bags (Welch Fluorocarbon, Inc., Dover, NH, USA). The bags were closed with double sets of pull-ties and placed in transport coolers (PeliCase coolers, Pelican Products, Inc., Torrance, CA, USA). Free space in the PeliCase coolers were packed with frozen wet towels, and temperature loggers were placed in each cooler, with temperatures logged every $30 \mathrm{~min}$. The seawater samples were transported by boat to the mainland, and by plane from Ilulissat to SINTEF's laboratories in Trondheim, Norway. The seawater arrived at SINTEF on 14. September 2016 and was placed at $4{ }^{\circ} \mathrm{C}$ until start of the experiment. The seawater transport in the coolers secured low temperatures, with a median temperature of $4-5^{\circ} \mathrm{C}$ during the first $28 \mathrm{~h}$, followed by a slow median increase to $7{ }^{\circ} \mathrm{C}$ before the coolers reached our laboratories after $52 \mathrm{~h}$ of transport. Only one cooler reached a peak of $9{ }^{\circ} \mathrm{C}$ the last hour before it was placed at $4-5{ }^{\circ} \mathrm{C}$ (Online Resource 3$)$.

Temperate seawater was collected from the Trondheimsfjord (TRD; $63^{\circ} 26^{\prime} \mathrm{N}, 10^{\circ} 23^{\prime} \mathrm{E}$ ), from the upper 0 to $0.5 \mathrm{~m}$ of the surface $(60 \mathrm{~L})$ in $10 \mathrm{~L}$ barrels (10. September 2016). Seawater temperature was $11^{\circ}$ when sampled. The seawater was transported to the SINTEF laboratories and placed at $4{ }^{\circ} \mathrm{C}$ until start of the experiment.

Surface and subsurface seawater samples from DB (approximately $1 \mathrm{~L}$ ) were filtered on-site for microbial community analyses (surface and subsurface) in triplicate samples through $0.22 \mu \mathrm{m}$ Durapore membrane filters, and the filters placed in Eppendorf tubes. Filters with DB seawater were placed in Isopore boxes with frozen cooling elements, transported in the PeliCase coolers together with the seawater, and stored at $-20{ }^{\circ} \mathrm{C}$ after arrival at SINTEF.

\section{Biodegradation experiment}

A biodegradation experiment was started on 19. September 2016. A fresh naphthenic oil (Troll C; pour point $-18{ }^{\circ} \mathrm{C}$, density of $0.900 \mathrm{~g} \mathrm{~cm}^{-3}$ ) was mixed with the dispersant Corexit 9500A (Nalco Environmental Solutions LLC, Sugar Land, TX, USA) at a dispersant-to-oil ratio (DOR) of 1:100. An oil-droplet generator was used for preparing oil dispersions with defined droplet size distributions, as previously described (Nordtug et al. 2011). The system consists of three chambers with an inner diameter of $8 \mathrm{~mm}$ connected by nozzles with a diameter of $0.5 \mathrm{~mm}$. Stock oil dispersions with defined oil-droplet size distributions (median diameter $20 \mu \mathrm{m})$ and concentrations ( $200 \mathrm{mg} \mathrm{L}^{-1}$ ) were generated by injecting oil via a capillary into a flow of non-amended filtered $\left(1 \mu \mathrm{m}\right.$ exclusion limit) seawater (acclimated to $4-5{ }^{\circ} \mathrm{C}$ for 5 days) moving through the chambers of the droplet generator. Oil-droplet concentrations and size distribution were determined by Coulter Counter analyses (see below).

Flasks (2 L; Schott) were baked, washed, sterilized, and filled with corresponding seawater (acclimated to $4-5{ }^{\circ} \mathrm{C}$ for 5 days) from the different water sources. Oil dispersion stock solutions were diluted in unfiltered seawater to nominal concentrations of $3 \mathrm{mg} \mathrm{L}^{-1}$, based on Coulter Counter analyses (see below). Flasks were completely filled with the respective seawater to avoid any headspace or air bubbles and capped (PBT screw caps and PTFE protected seal). The flasks were immediately mounted on a carousel system with slow continuous axial rotation ( 0.75 r.p.m), as previously described (Brakstad et al. 2015a). The dispersions were incubated on the carousel system at $4-5{ }^{\circ} \mathrm{C}$ for up to 64 days. This temperature corresponded to the surface seawater temperature in DB during water sampling (Supplementary Material, Online Resource 2). Seawater blanks containing only unfiltered seawater without oil were also included in the experiment. Flasks with dispersions in Arctic seawater from surfaced or subsurface (triplicate), and temperate seawater from surface (triplicate) were sampled for analyses after 0 (15 min on carousels), 7, 14, 21, 28, 42, and 64 days. Seawater blanks from all three localities were sampled similarly (one replicate of each).

\section{Particle analyses}

Oil-droplet concentrations and size distributions in $20 \mathrm{~mL}$ samples (triplicate) were determined by Coulter Counter measurements (Beckman Multisizer 4; Beckman Coulter Inc., Brea, CA, USA) fitted with a $100 \mu \mathrm{m}$ aperture for measurement of droplets size and concentrations within a diameter range of $2-60 \mu \mathrm{m}$. Filtered $(0.22 \mu \mathrm{m})$ seawater was used as electrolyte. All droplet sizes reported here are expressed as median droplets diameter.

\section{Chemical analyses}

Samples of oil dispersions and seawater blanks $(1 \mathrm{~L})$ were acidified $(\mathrm{pH}<2)$ and solvent-solvent extracted with dichloromethane (DCM) for measurements of semivolatile organic compounds (SVOC). The flask glass walls and interior of lids were also rinsed with DCM after removal of dispersions to extract material attached to the glass walls. GC-FID analyses (Agilent $6890 \mathrm{~N}$ with $30 \mathrm{~m}$ DB1 column; Agilent Technologies) were used for quantification of total extractable material (TEM), representing mainly saturates (linear, branched and cyclic alkanes). GC-MS analyses (Agilent 6890 plus GC coupled with an Agilent 5973 MSD detector, operated in Selected Ion Monitoring [SIM] modus; Agilent Technologies) were used for analyses of targeted SVOC compounds, including $n \mathrm{C}_{10}-n \mathrm{C}_{36} \mathrm{n}$-alkanes, decalines, phenols, 2- to 5-ring polyaromatic hydrocarbons (PAHs) and $17 \alpha(\mathrm{H}), 21 \beta(\mathrm{H})$-Hopane (30ab Hopane), as recently described (Brakstad et al. 2014). For analyses of volatile organic compounds (VOCs), dispersions or seawater blanks $(40 \mathrm{ml})$ were acidified $(\mathrm{pH}<2)$ and analysed for targeted 
compounds $\left(\mathrm{C}_{5}-\mathrm{C}_{10}\right.$ alkanes and monoaromatic hydrocarbons) in a Purge \& Trap unit (Teledyne Tekmar Atomx; Mason OH, USA) coupled to a GC-MS (Agilent $6890 \mathrm{~N}$ GC and an Agilent 5975B MSD detector; Agilent Technologies) (P\&T GC-MS). The response values for individual target analytes were determined, with a signal-to-noise ratio of 10 as the lower detection limit, and a lower limit of detection (LOD) of $0.01 \mu \mathrm{g} \mathrm{L}{ }^{-1}$ was defined for all individual oil compounds analysed by GC-MS (VOC and SVOC), while a LOD for GC-FID analyses (TEM) was $0.1 \mu \mathrm{g} \mathrm{L}^{-1}$. VOC and SVOC compounds were grouped in 23 of the oil compound groups described for the OSCAR oil spill model (Reed et al. 2000; see Online Resource 4).

\section{Microbial counts}

Tenfold dilutions in deionized water of oil dispersions or seawater samples were incubated in 4',6-diamidino-2-phenylindole (DAPI; $0.2 \mu \mathrm{g} \mathrm{mL}{ }^{-1}$ ) for $10 \mathrm{~min}$, and filtered through $0.2 \mu \mathrm{m}$ black polycarbonate filters (Nucleopore, Costar, Cambridge, MA, USA). Total counts of prokaryotic cells were enumerated by oil immersion fluorescence microscopy at 1250 times magnification. Ten individual counts were performed and concentrations (cell $\mathrm{mL}^{-1}$ sample) determined based on an ocular lattice system and dilution used for counting.

Most probable number (MPN) analyses of aerobic heterotrophic prokaryotes (HP) and oil-degrading prokaryotes (ODP) were performed in tenfold dilutions of sterile-filtered $(0.22 \mu \mathrm{m})$ seawater. Each dilution $(0.2 \mathrm{~mL})$ was applied in triplicate to $1.8 \mathrm{~mL}$ Marine Broth 2216 (Difco Labs, Detroit, MI, USA) in 24-well tissue culture plates (Costar) for HP analyses, or to $1.8 \mathrm{ml}$ while Bushnell-Haas broth (Difco) in 24-well tissue culture plates, supplemented with $30 \mathrm{~g} \mathrm{~L}^{-1}$ $\mathrm{NaCl}$ and with $0.1 \%$ (vol/vol) fresh oil (Troll) as carbon source. The MPN-plates for HP were incubated at $4-5{ }^{\circ} \mathrm{C}$ for 7 days. The plates were then incubated at room temperature for 3 days to boost the growth in wells with dubious growth, before final analyses. Based on previous experience with slow growth at $4-5{ }^{\circ} \mathrm{C}$, MPN-plates for analyses of ODP were incubated at room temperature for 14 days before recording. At the end of the test, actively respiring ODP cultures were detected by adding $100 \mu \mathrm{l}$ fluorescein diacetate $\left(0.1 \mathrm{mg} \mathrm{mL}^{-1}\right.$ final concentration) to each well with Bushnell-Haas media for $60 \mathrm{~min}$ before the results were recorded. Growth was recorded with respect to dilution, and final concentrations of viable HP and ODP determined from standard MPN tables.

\section{Microbial community analyses}

Samples $(500 \mathrm{~mL})$ collected during biodegradation were filtered through $0.22 \mu \mathrm{m}$ Durapore filters, and filters placed in Eppendorf tubes and frozen $\left(-20{ }^{\circ} \mathrm{C}\right)$. DNA samples on filters with Arctic or temperate seawater, and from the biodegradation experiment, were extracted by FastDNA Spin kit for soil (MP Biomedicals), according to the manufacturer's instructions. DNA yields were quantified using Qubit 3.0 (Thermo Fisher Scientific, MA, USA) with dsDNA High Sensitivity kit (ThermoFisher Scientific, MA, USA). 16S rDNA amplicons were generated by PCR using primer combinations targeting the V3 and V4 hypervariable regions of bacterial 16S rRNA genes (Klindworth et al. 2013). Primers were tagged with Illumina adapter overhang and hot-start PCR performed (Eppendorf Mastercycler) to generate 16S rDNA amplicons. The generated amplicons were isolated using PCR clean-up spin columns (Qiagen; QIAquick Gel Extraction Kit), and thereafter used in index PCR with Illumina NEXTERA XT indices. Indexed 16S amplicons were isolated using PCR clean-up spin columns, verified and quantified (Qubit 3.0), and DNA indexed amplicons were diluted and pooled for generation of a library for sequencing. DNA library and Illumina positive control PhiX samples were thereafter denatured. DNA library pool and PhiX were then incubated at $96^{\circ} \mathrm{C}$ for 2 min before running in an Illumina MiSeq sequencer according to Illumina's 16S rRNA sample preparation guideline.

16S rRNA gene sequences were analysed using QIIME pipeline (Caporaso et al. 2010) and R language package Phyloseq (McMurdie and Holmes 2013), and the reads were checked for chimaera sequences against ARB Silva database. Operational taxonomic units (OTUs) were based on cut-off of $97 \%$ of sequence similarity, and taxonomy assignment was performed with RDP classifier (Wang et al. 2007). The raw reads of each OTU were converted to relative abundances and taxa were agglomerated on the desired taxonomic level between replicates of the identical sampling point for the purpose of OTU comparison across incubation days and treatments. Representation of the most abundant prokaryotes was obtained by selecting the taxa that contained at least $10 \%$ of abundance at any time point. Taxa with relative abundances less than $10 \%$ were assigned as "Other".

\section{Other analyses}

Dissolved oxygen (DO) and water temperatures were determined by a DO meter (YSI, Inc., Yellow Springs, OH, USA).

Nutrient analyses of seawater included total Nitrogen (internal procedure), $\mathrm{NO}_{3}+\mathrm{NO}_{2}-\mathrm{N}$ (ISO 13395), $\mathrm{NH}_{4}-\mathrm{N}$ (ISO 11732), $o-\mathrm{PO}_{4}-\mathrm{P}$ and total Phosphorous (both ISO 15681-2), Iron (ISO 17294-2:2016), and total organic carbon (TOC) (EN 1484), all analysed by Eurofins Environment Testing Norway, Bergen, Norway. 


\section{Data treatment and statistics}

Non-linear regression analyses were performed by the option "plateau followed by one-phase decay" in GraphPad Prism vs. 6.0 (GraphPad Software Inc., La Jolla, CA, USA). The "plateau" represented the non-responsive lag-periods. Halflives were determined from rate coefficients $\left(t_{1 / 2}=0.693 / k 1\right)$. We were unable to categorically exclude abiotic losses for volatile oil compounds analysed by P\&T GC-MS, since sterilized controls were not included and these compounds could not be normalized against 30ab Hopane. Revised biotransformation half-lives $\left(t_{1 / 2 \text {-rev }}\right)$ and rate coefficients $\left(k 1_{\text {rev }}\right)$ were determined, in which the influences of the nonresponsive lag-periods also were accounted for: $t_{1 / 2 \text {-rev }}=$ lagperiod $+t_{1 / 2}$, and $k 1_{\text {rev }}=0.693 / t_{1 / 2 \text {-rev }}$. For comparison, biotransformation rate coefficients and half-lives were determined as standard first-order rates ("one-phase decay"; GraphPad Prism), without including any lag-periods in the calculations. The determination of rate coefficients $(k 1)$ and half-lives $\left(t_{1 / 2}\right)$ by standard first-order rates, and the determination of revised rate coefficients $\left(k 1_{\text {rev }}\right)$ and half-lives $\left(t_{1 / 2 \text {-rev }}\right)$, are described for the OSCAR group PAH- 1 in DB surface seawater in Online Resource 5).

$Q_{10}$ calculations of rate coefficients at $5{ }^{\circ} \mathrm{C}\left(k 1_{5}\right)$ were made with rate coefficients from experimental data generated at $13{ }^{\circ} \mathrm{C}, k 1_{13}$ (Brakstad et al. 2018a), based the equation $Q_{10}=2$ (rate coefficients increased by a factor of 2 for temperature increase of $10{ }^{\circ} \mathrm{C}$ ): $k 1_{5}=k 1_{13} \times 10^{0.03(t 5-t 13)}$, were 0.03 is a $Q_{10}$ conversion factor, and $t_{5}$ and $t_{13}$ represent the temperatures of 5 and $13{ }^{\circ} \mathrm{C}$, respectively (Bagi et al. 2013).

Column statistics were compared by Wilcoxon matched paired $t$ test in GraphPad Prism vs. 6.

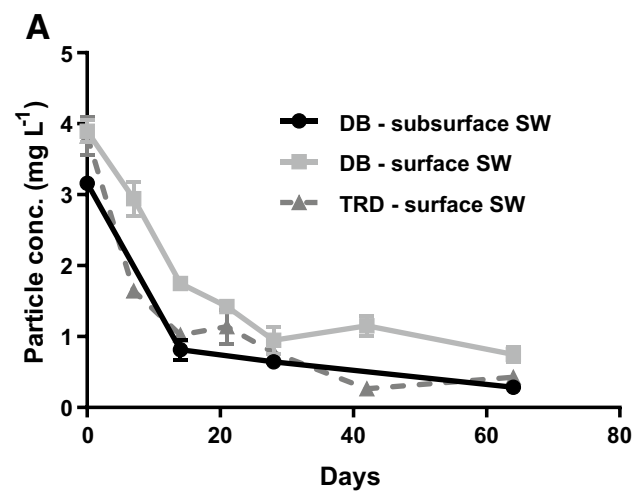

\section{Results}

\section{Seawater sampling and transport}

Vertical CTD monitoring of the water column at the sampling site in DB (Online Resource 2 ) showed a surface temperature of $5{ }^{\circ} \mathrm{C}$, slowly decreasing to approximately $2{ }^{\circ} \mathrm{C}$ at $80 \mathrm{~m}$ depth. Lower salinity and density of the DB surface seawater compared to the deeper water was probably caused by ice melting and freshwater run-off from land. The surface SW temperature in the TRD seawater was $11.2{ }^{\circ} \mathrm{C}$ when sampled.

The concentrations of macronutrient and total organic carbon (TOC) in the Arctic (DB) and temperate (TRD) seawaters are shown in Online Resource 6. The macronutrient conditions differed between the DB and TRD surface seawater, with significantly lower concentrations of both $\mathrm{N}$ - and $\mathrm{P}$-compounds in the former. Differences were also measured between the DB surface and subsurface seawater, with higher $\mathrm{N}$ and $\mathrm{P}$ concentrations in the subsurface than the surface seawater. However, significantly higher $\mathrm{NH}_{4}-\mathrm{N}$ concentrations occurred in the TRD surface seawater (Online Resource 6).

\section{Oil droplets, temperature and oxygen}

At the start of biodegradation experiment, the oil-droplet concentrations were between 3 and $4 \mathrm{mg} \mathrm{L}^{-1}$ in the DB and TRD dispersions (average $3.6 \pm 0.4 \mathrm{mg} \mathrm{L}^{-1}$ ), while the median droplet sizes of the dispersions were $17.1 \pm 2.3 \mu \mathrm{m}$ (Fig. 1), close to the nominal conditions set on the oil-droplet generator. During the biodegradation experiment the droplet concentrations rapidly declined in all dispersions, and at the end of the experiment (64 days) the concentrations were reduced to an average of $0.4 \pm 0.3 \mathrm{mg} \mathrm{L}^{-1}$ in DB and TRD dispersions (11\% of initial concentrations),

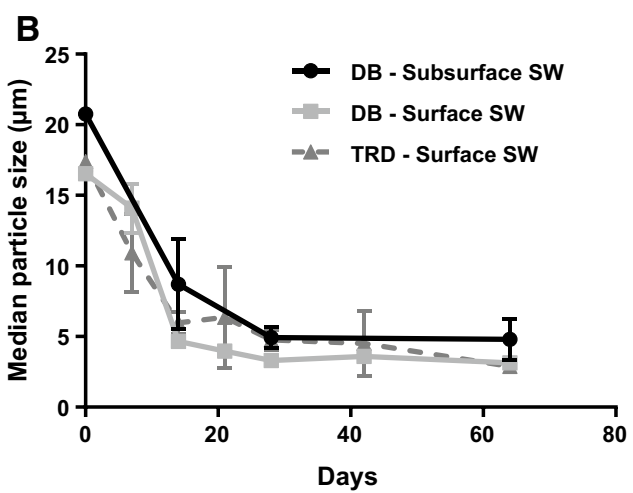

Fig. 1 Oil-droplet concentrations (a) and median oil-droplet sizes (b) in dispersions with surface and subsurface seawater (SW) from DB and surface SW from TRD. Error bars represent standard deviations of triplicate analyses 
irrespective of seawater source. The median oil-droplet sizes were rapidly reduced in the DB and TRD dispersions, averaging $5.1 \pm 4.4 \mu \mathrm{m}$ at the end of the experiment. In conjunction with the reduced oil-droplet concentrations, macroparticles expected to include oil and biomass were observed (Online Resource 7). The average seawater temperature in the DB and TRD dispersions during the experiment was $5.4 \pm 0.9^{\circ} \mathrm{C}$. DO in the dispersions at the start of the study averaged $9.0 \pm 0.5 \mathrm{mg} \mathrm{L}^{-1}$, and was never lower than $5.9 \mathrm{mg}$ $\mathrm{L}^{-1}$ in any flask during the study, averaging $7.6 \pm 1.2 \mathrm{mg} \mathrm{L}^{-1}$ at the end of the study (day 64).

\section{Depletion and biotransformation of targeted oil compounds}

Measurements of TEM concentrations substantiated that reductions in oil-droplet concentrations were not the result of oil disappearances in the dispersions, since TEM concentrations were only negligible or moderately reduced compared to the oil-droplet concentrations. Only the dispersions in the TRD surface seawater showed significant reduction in TEM concentrations $(p=0.0047)$ during the experiment, with $39.4 \pm 7.0 \%$ decline after 64 days. The dispersions in DB surface and subsurface seawater showed insignificant depletion ( $p=0.6297$ in surface and 0.5399 in subsurface seawater), as shown in Fig. 2 a. However, $n$-alkane depletion was substantial, with $>90 \%$ reduction in all dispersions (averaging $95.4 \pm 2.3 \%$ ) after 64 days of incubation (Fig. 2b). Depletion of 2- to 5-ring PAH was more than 50\% in all dispersions after 64 days degradation period (Fig. 2c), but higher in TRD surface seawater $(93.3 \pm 0.2 \%)$ than in DB surface seawater $(65.4 \pm 7.5 \%)$ and subsurface seawater $(55.4 \pm 12.6 \%)$. Reductions of VOC compounds were faster in the TRD and DB surface seawater (average $99.7 \pm 0.4 \%$ ) than in the DB subsurface seawater $(45.6 \pm 1.0 \%)$ after 64 days (Fig. 2d).

Biotransformation was examined in the dispersions after normalization against the persistent biomarker $17 \alpha(\mathrm{H}), 21 \beta(\mathrm{H})$-hopane (30ab hopane), commonly used in biodegradation studies (Prince et al. 1994; Wang et al. 1998). No depletion of 30ab hopane was measured during the experiment (Online Resource 8). Biotransformation of single $n$-alkanes in all dispersions were insignificant after 7 days of incubation (not shown), while transformation of $n \mathrm{C}_{15}-n \mathrm{C}_{26}$ alkanes were determined in all dispersions after 14 days of incubation (Fig. 3a). Biotransformation was faster for $n \mathrm{C}_{15}-n \mathrm{C}_{26}$ alkanes than $>n \mathrm{C}_{26}$ alkanes in DB and TRD dispersions, and degradation of the larger alkanes occurred faster in the DB and TRD surface seawater than in the DB subsurface seawater (Fig. 3b, c). After the 64 days biodegradation period, the depletion of the higher $n$-alkanes $\left(>n \mathrm{C}_{30}\right)$ was less complete in both DB seawaters compared to the TRD seawater (Fig. 3c), except for $n \mathrm{C}_{36}$. However, a low concentration of this $n$-alkane resulted in a high standard deviation (Fig. 3c). The biotransformation of single 2- to 4-ring PAH compounds was also faster in the DB and TRD surface seawater than in the DB subsurface seawater, with more extensive depletion in the TRD than the DB seawater at the end of the experiment. The biotransformation followed a pattern
Fig. 2 Concentrations of TEM (a), $n \mathrm{C}_{10^{-}}$to $n \mathrm{C}_{36}$ alkanes (b), total 2- to 5-ring PAH (c) and total VOC (d; the sum of $\mathrm{C}_{5}-$ $\mathrm{C}_{10}$ alkanes and monoaromatic hydrocarbons) in seawater (SW) from DB and TRD. Error bars represent standard deviations of triplicate analyses
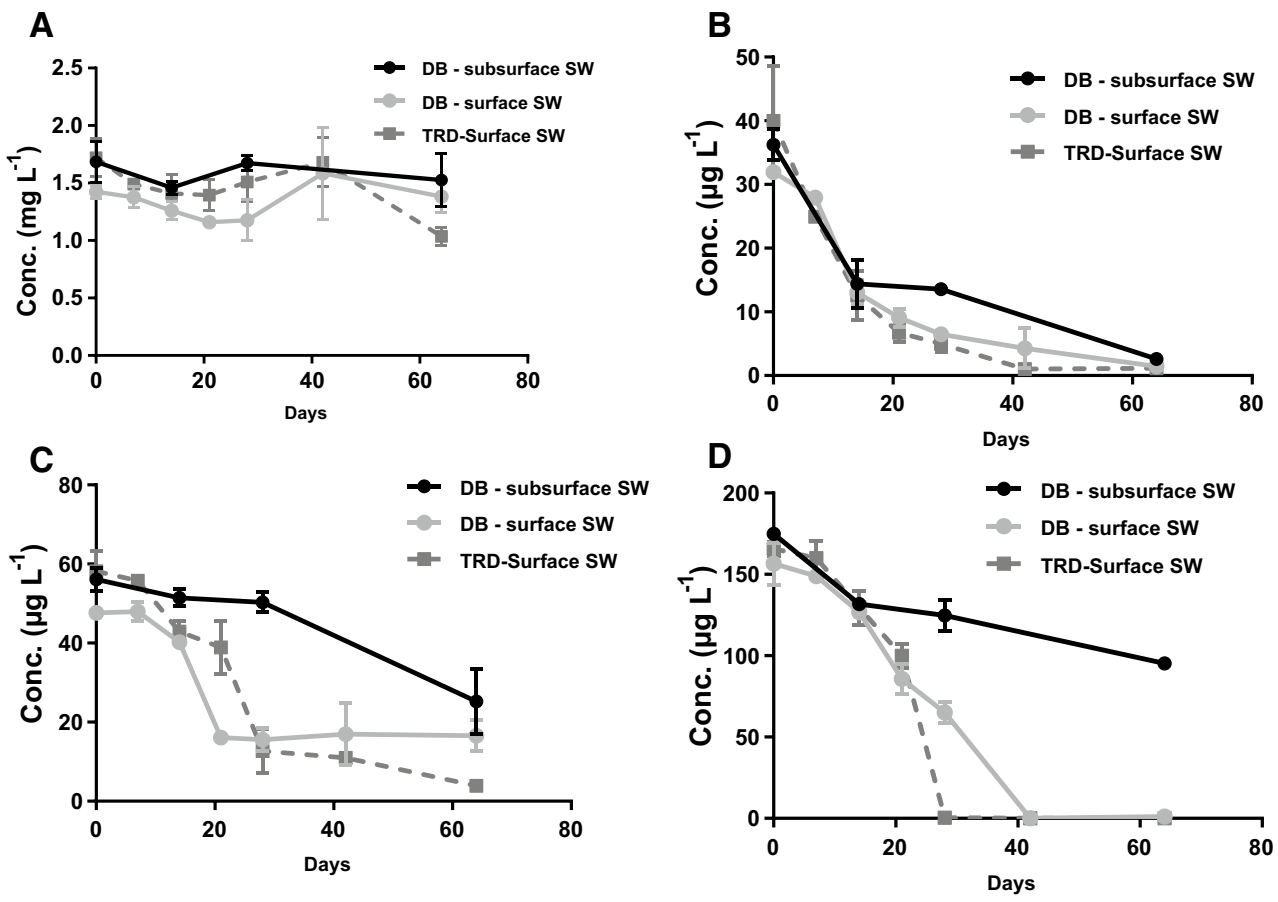

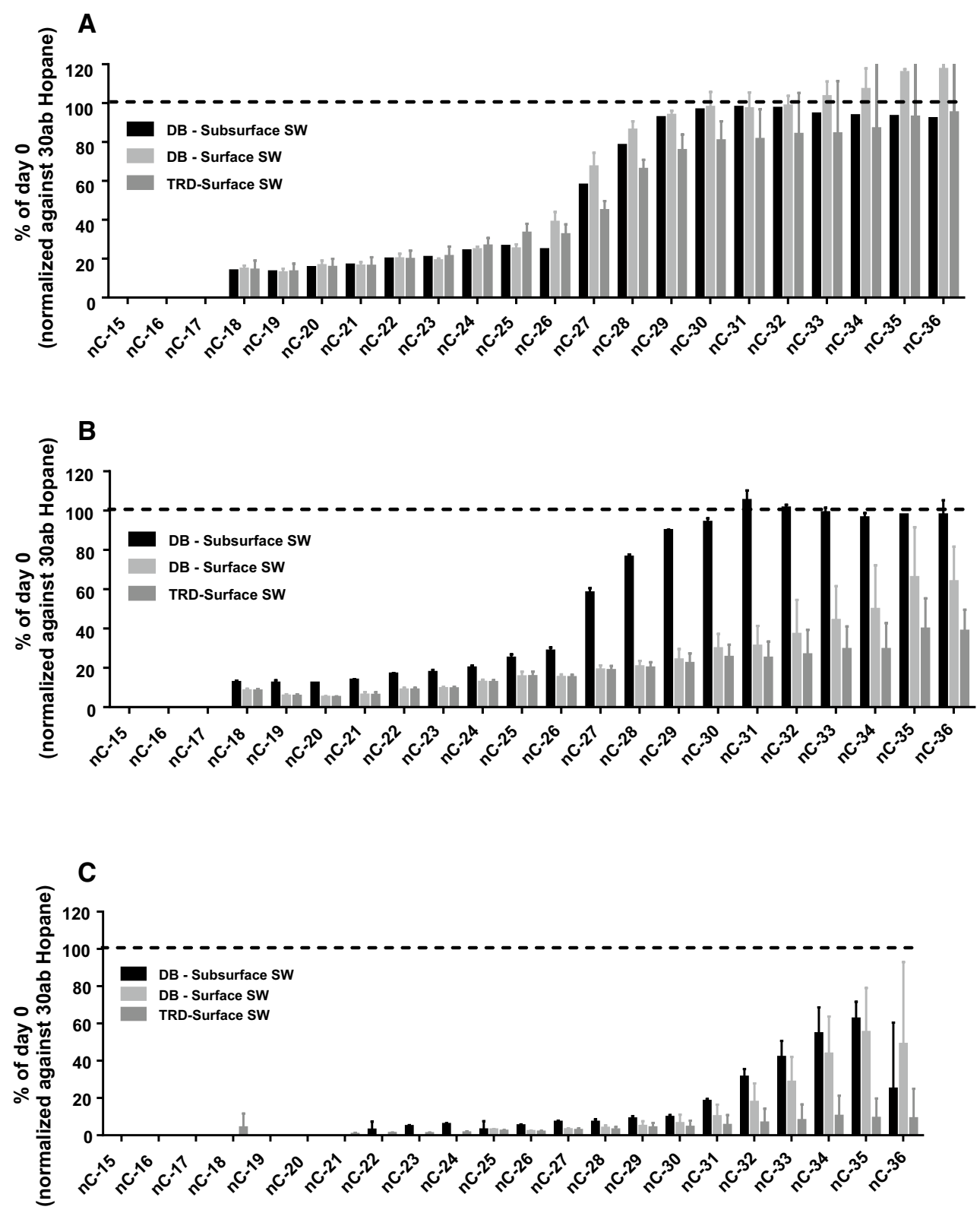

Fig. 3 Biotransformation (\% of day 0) of individual semivolatile $n$-alkanes $\left(n \mathrm{C}_{15}-n \mathrm{C}_{36}\right)$ in oil dispersions with seawater (SW) from $\mathrm{DB}$ and TRD, after normalization of target analytes against 30ab hopane.

with slower transformation by increasing alkyl substitution (Fig. 4), in agreement with previous measurements of chemically dispersed oil (Brakstad et al. 2015a). Depletion of single volatile compounds (alkanes and BTEX) were also examined, although these could not be normalized against any biomarker. Typically, the BTEX were depleted slower in the DB subsurface seawater than in the DB and TRD surface seawater (Online Resource 9).
The data are shown after incubations for 14 days (a), 28 days (b) and 64 days (c). Error bars represent standard deviations of triplicate analyses

\section{Biotransformation rates and half-lives of oil compound groups}

The SVOC and VOC compounds analysed by GC-FID, GC-MS and P\&T GC-MSn, with boiling point ranges of $27->500{ }^{\circ} \mathrm{C}$, are considered to represent $70-80 \%$ of typical crude oils (Pasquini and Bueno 2007). These oil fractions were separated in 23 of total 25 OSCAR volatile and 

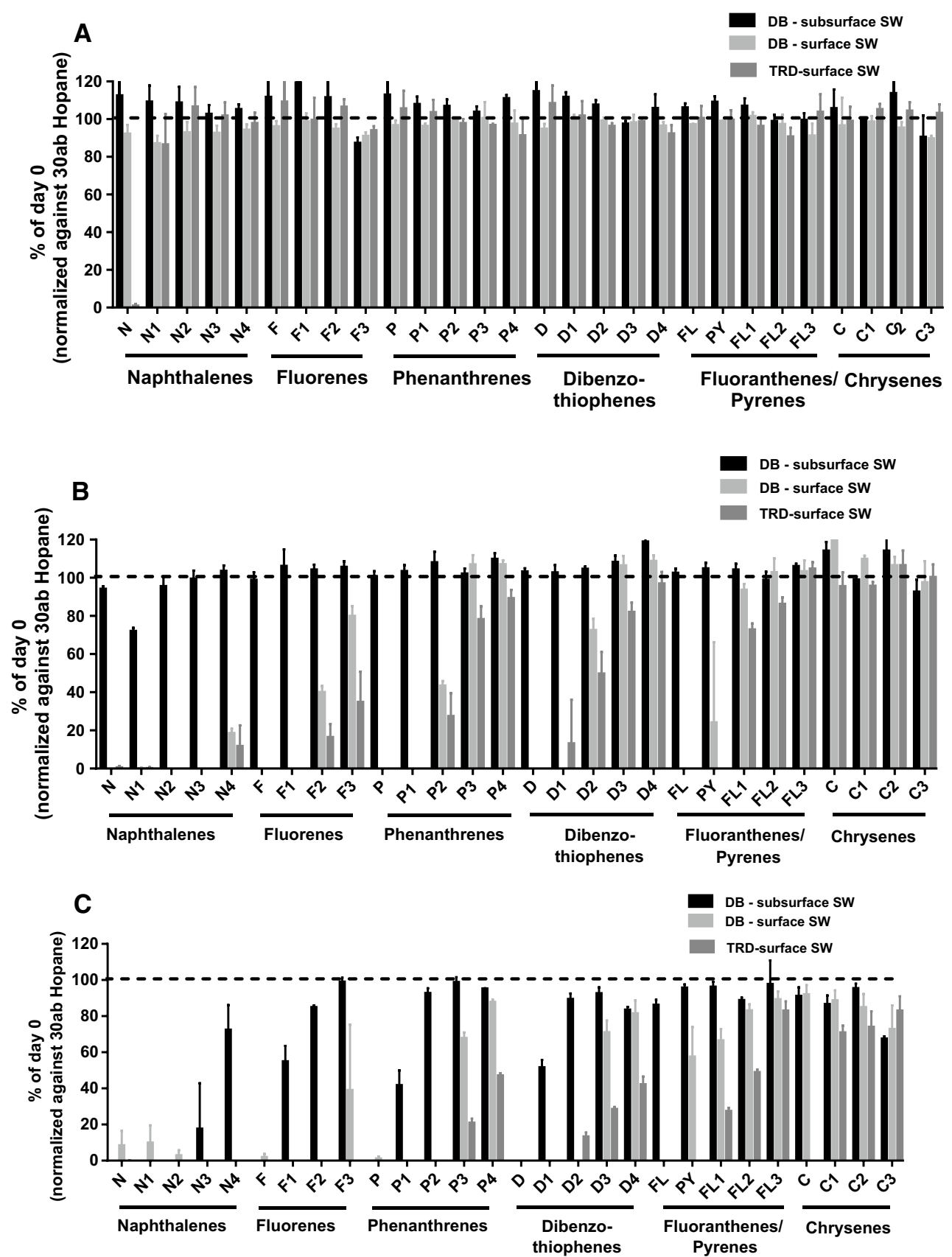

Fig. 4 Biotransformation (\% of day 0 ) of individual semivolatile 2- to 4-ring PAH in oil dispersions with seawater (SW) from DB and TRD, after normalization of target analytes against 30ab hopane. The data

semivolatile groups described in Online Resource 4 (Reed et al. 2000), but concentrations of phenols and $C_{9}$ saturates in the Troll oil were below analytical LOD and could not be included in the calculations. Revised biotransformation half-lives $\left(t_{1 / 2-\text {-rev }}\right.$; see Materials and methods and Online Resource 5) determined for each of these groups, including $\mathrm{C}_{5}-\mathrm{C}_{36}$ saturates, monoaromatic hydrocarbons, naphthalenes, and 2- to 5-ring PAH, are shown in Fig. 5, based are shown after incubations for 14 days (a), 28 days (b) and 64 days (c). Error bars represent standard deviations of triplicate analyses

on the transformation rate data shown in Online Resource 10. Revised half-lives of the compound groups ranged from 15 to $>500$ days, with the small aromatic hydrocarbons (BTEX and naphthalenes with the shortest halflives (15-44 days). These compounds showed generally shorter biotransformation half-lives in the DB and TRD surface seawater (median half-lives of $15.7 \pm 2.2$ days in DB and $16.9 \pm 2.7$ days in TRD) than in the DB subsurface 


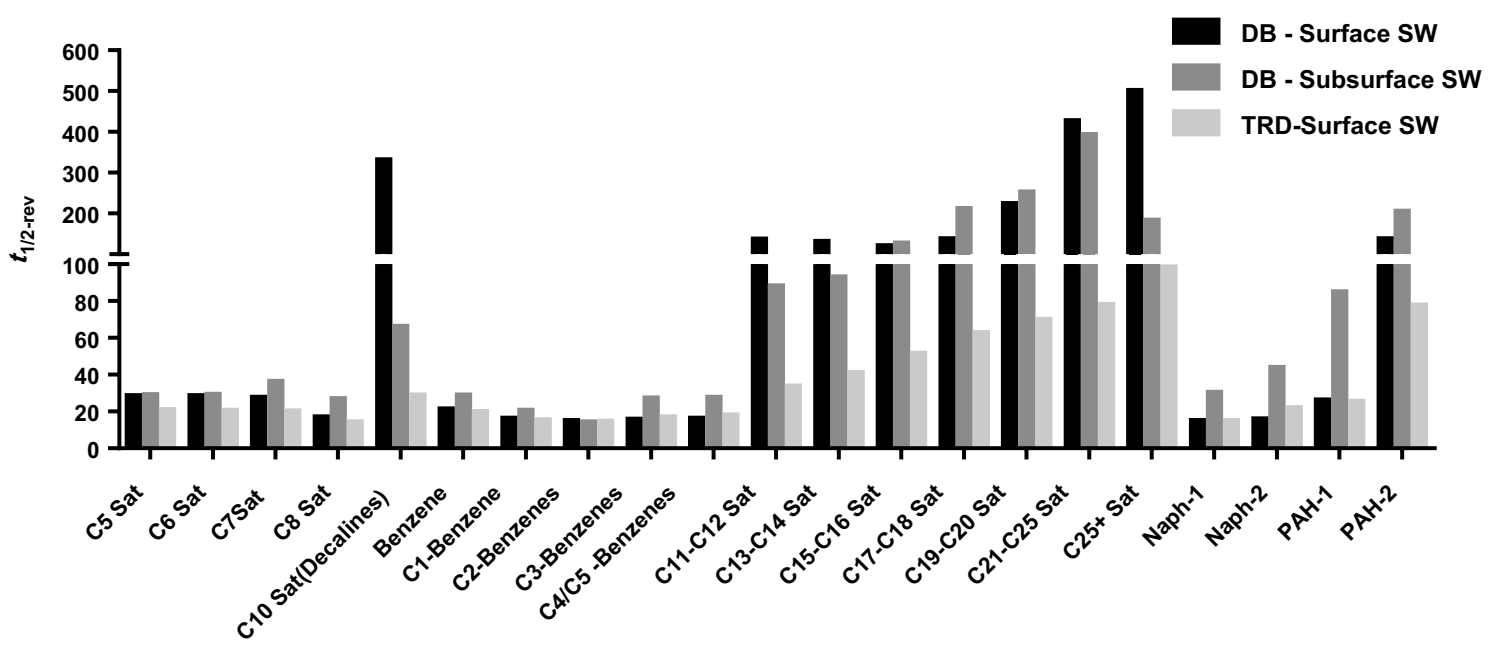

OSCAR Group

Fig. 5 Revised half-lives $\left(t_{1 / 2 \text {-rev }}\right)$ of VOC and SVOC oil compound groups determined from oil biotransformation kinetics in DB surface and subsurface seawater (SW) and TRD surface SW. The revised half-lives were determined as described in Materials and methods

seawater (median half-life $27.4 \pm 9.1$ days). The revised half-lives of the semivolatile saturates $\left(\mathrm{C}_{10}-\mathrm{C}_{25}+\right.$ Sat $)$ were considerably shorter in the TRD surface seawater (median half-lives of $57.0 \pm 23.8$ days) than in the DB seawaters (median half-lives of $180 \pm 120$ days in surface and $154 \pm 109$ days in subsurface seawater). The slower biotransformation of the quantitatively predominant saturates in the DB surface seawater could possibly be related to the low macronutrient concentrations in this water (Online Resource 6). Finally, the half-lives of the larger 4- to 5-ring PAH (PAH-2) were also higher in the DB than the TRD seawater. Comparison of the data sets showed that the TRD data differed significantly ( $t$ test, $p \geq 0.0005$ ) from both DB data sets, while the DB data did not differ significantly from each other $(p=0.3554)$. The revised half-lives of each seawater source (Online Resource 10) were also compared to half-lives determined from rate coefficients, in which lag-periods were not included in any calculations (Online Resource 11). No significant differences were determined ( $t$ test, $p$ value ranging from 0.0905 to 0.3472 ) between calculation methods, although longer half-lives were determined for several saturates when lag-periods were not included in the calculations (Online Resource 11).

In the OSCAR model, temperature calibrations of biodegradation rates are performed by $Q_{10}$ calculations, using biotransformation data provided from experiments at $13{ }^{\circ} \mathrm{C}$. Comparison of rate coefficients and half-lives calculated by $Q_{10}$ approach $\left(Q_{10}=2\right)$ for $5{ }^{\circ} \mathrm{C}$ from experimental data at $13{ }^{\circ} \mathrm{C}$ (Brakstad et al. 2018a) showed that rate coefficients of semivolatile OSCAR groups were overestimated by the $Q_{10}$ method (Online Resource 12) when compared to the experimental data at $5{ }^{\circ} \mathrm{C}$ (Online Resource 11), and all experimental data sets differed significantly from the $Q_{10}$ calculations ( $t$ test, $p \leq 0.001$ ).

\section{Microbial concentrations and communities}

The low oil concentrations used in the current study did not result in increased total concentrations of microbes in the dispersions, although the concentrations were generally higher in the oil dispersions than in seawater without oil, which was incubated at the same conditions (Fig. 6a). MPN analyses of HP (Fig. 6b) showed in general stimulation of growth in oil dispersions, compared to in seawater without oil after 28 and 64 days of incubation. The concentrations of ODP (Fig. 6c) were low, but they were mainly higher in the TRD seawater than DB seawater after 14 and 28 days, which represented the main period of $n$-alkane, PAH and VOC compound degradation (see Fig. 2). However, ODP were also detected in several samples without oil, particularly at the end of the biodegradation period (day 64).

The microbial communities at the start of the biodegradation experiment differed between the seawater sources. The DB subsurface and surface seawater was predominated by Polaribacter (Flavobacteriaceae) and Sulfitobacter (Rhodobacteraceae), with additional abundances of Colwellia and Moratella (Alteromonadales) in DB subsurface seawater and Persicirhabdus (Verrucomicromicrobiaceae) in DB surface seawater. These bacterial groups were also abundant in the original DB seawaters sampled and filtered before transport (results not shown). TRD communities were predominated by Rhodobacteraceae and Synechococcus (Fig. 7). Bacterial successions were observed in the oil dispersions, 

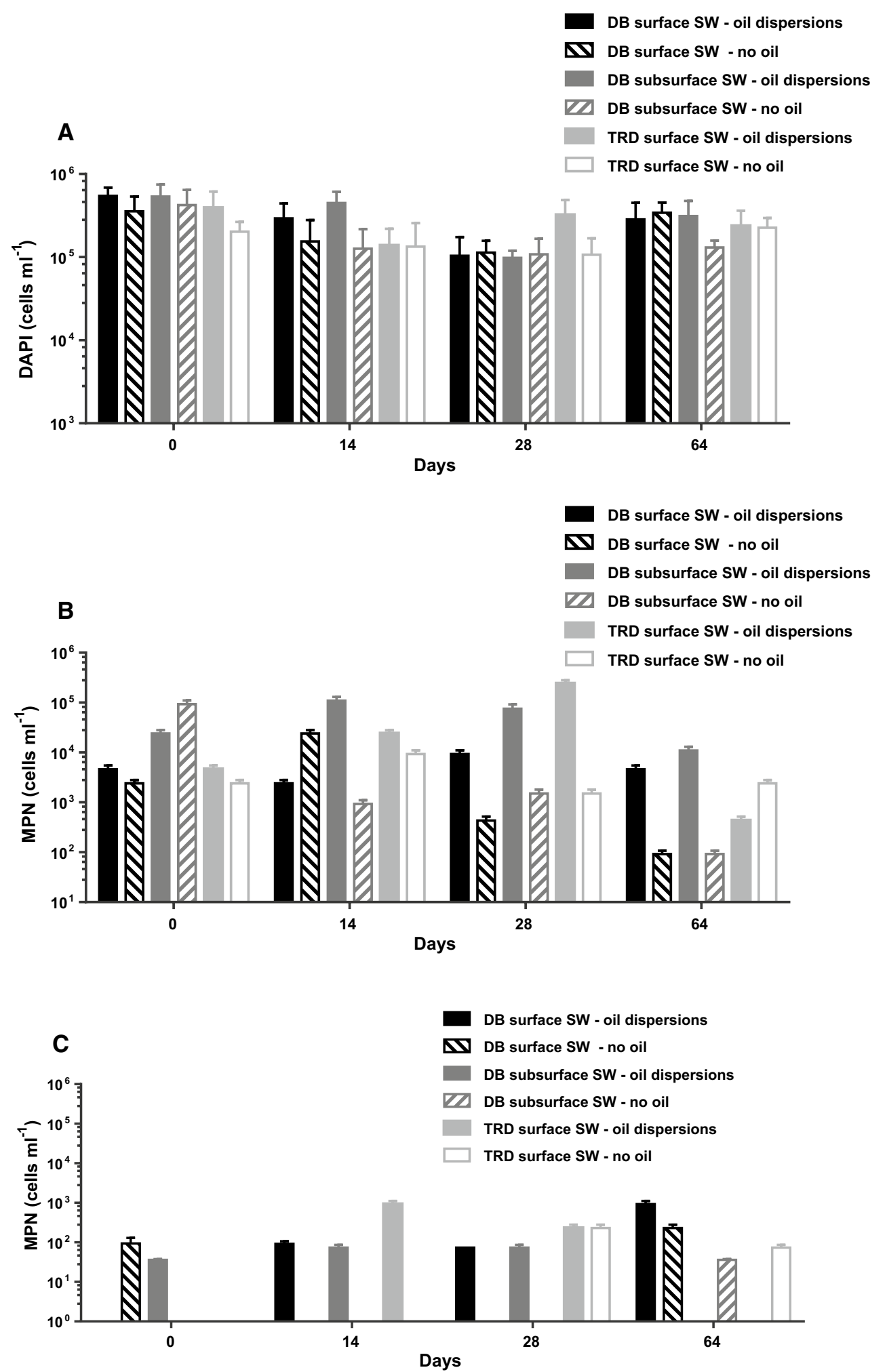

Fig. 6 Microbial concentrations determined as total concentrations by epifluorescence microscopy (a), and MPN enumeration of heterotrophic prokaryotes (b) oil-degrading prokaryotes (c) in seawater
(SW) from DB and TRD. Error bars represent standard deviations of epifluoresence counts, or $95 \%$ confidence intervals of MPN enumerations 


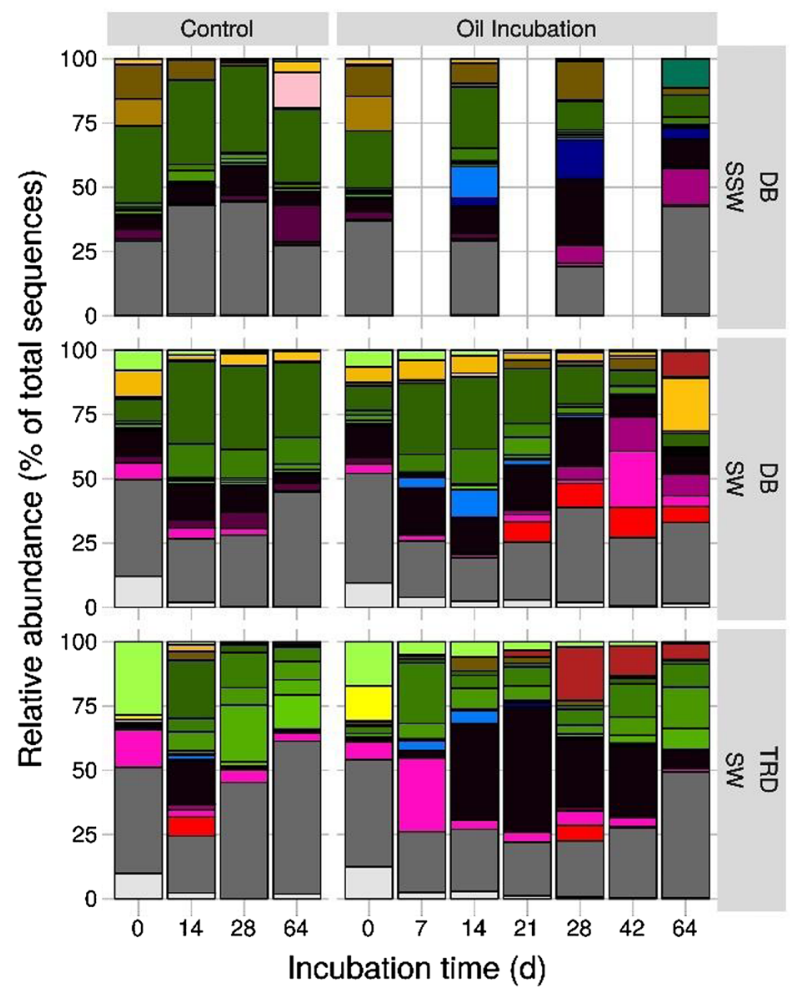

Fig. 7 The relative abundances among the microbial taxa (genus level) that represented $\geq 10 \%$ of the total sequences in each sample. The relative abundances are shown by sampling day for seawaters

with changes after 14-28 days of incubations. The abundances of Oleispira (Oceanospirillaceae) and Ulvibacter (Flavobacteriaceae) increased in all oil dispersions during the first 14 days, while Polaribacter (Flavobacteriaceae) became increasingly abundant only in the DB surface seawater. In the same period Sulfitobacter (Rhodobacteraceae) became increasingly abundant in the DB subsurface and TRD surface seawaters. Later in the biodegradation period (28-64 days) taxa with increased abundances in the oil dispersions included the genera of Pseudophaeobacter (Rhodobacteraceae) in both DB surface and subsurface seawater, Litorimonas (Hyphomonadaceae) and Pseudomonas in DB subsurface seawater, while Cycloclasticus (Piscirickettsiaceae) and Porticoccaceae abundances increased in both surface seawaters from DB and TRD.

\section{Discussions}

The seawater sampled from DB showed higher N/P ratios in the surface than the subsurface seawater. However, nitrate concentrations were higher in the subsurface seawater. The seawater was collected in September and could be affected by the previous algal blooming season, resulting in limited nitrate concentrations in the surface water. While the DB without oil (Control) and in oil dispersions (Oil Incubation) with subsurface seawater from DB (DB SSW), surface seawater from DB (DB SW) and TRD surface seawater (TRD SW)

macronutrient conditions show highly seasonal variations, the deeper water in DB is more stable (Hansen et al. 2012). Biological activities in the DB surface seawater were further substantiated by higher ammonium concentrations than in the subsurface DB seawater. The high ammonium concentrations occurring the TRD surface seawater indicated both higher $\mathrm{N}$-input and biological activities in this seawater compared to the DB surface seawater. Previous measurements of macronutrients in TRD subsurface seawater $(80 \mathrm{~m}$ depth) corresponded more to the DB subsurface seawater, with low ammonium concentrations (Brakstad et al. 2015a, b).

In the current studies, the oil was premixed with a dispersant, and dispersions were generated with oil-droplet sizes relevant for effective dispersant treatment of oil spills $(17.1 \pm 2.3 \mu \mathrm{m})$, and low oil-droplet concentrations were used (close to $3 \mathrm{mg} \mathrm{L}^{-1}$ ). It has been suggested that the use of dispersants may suppress the activities of oil-degrading bacteria, altering the microbial community composition through selection for potential dispersant-degrading bacteria like Colwellia in favour of oil-degrading bacteria (Kleindienst et al. 2015). No such suppression was observed in our studies. Recent studies with physically dispersed oil of similar oil-droplet sizes, premixed or not premixed with dispersant, have also shown that microbial communities 
and hydrocarbon biodegradation were comparable in the oil dispersions with and without dispersant premixing. The studies also showed that in solutions of dispersant alone (no oil), microbial communities were comparable to those in seawater without oil and dispersant (Brakstad et al. 2018b). The oil rather than the dispersant was therefore the driver for the microbial successions and biodegradation when dispersions were used.

During the biodegradation experiment, oil-droplet concentrations were rapidly reduced, probably as a combined result of droplet coalescence, glass wall attachment, and the observed flocculation of oil and biomass into macroparticles. The reduction in oil-droplet concentration has been measured in previous studies with dispersed oil biodegraded in subsurface ( $80 \mathrm{~m}$ depth) seawater from TRD (Brakstad et al. 2015a). The flocculation process and the characterization of these particles, consisting of the original oil, degradation products and biomass, has been reported in several studies (Macnaughton et al. 2003; Hazen et al. 2010; Bælum et al. 2012). Oil concentrations, measured as TEM, declined only moderately (TRD seawater) or negligible (both surface and subsurface DB seawater) in these studies, and the reductions were slower than previously measured in cold TRD subsurface seawater $\left(4-5^{\circ} \mathrm{C}\right)$ with a paraffinic Macondo oil (Brakstad et al. 2015a). The oil properties may have influenced the TEM degradation, since the Troll oil used in the current studies was an UCM-rich oil with low concentrations of rapidly degradable $n$-alkanes. This was further substantiated by the fact that target-specific degradation of $n$-alkanes here was comparable to the studies with the Macondo oil (Brakstad et al. 2015a). The $n$-alkanes were faster biotransformed than PAH and VOC, in particular in the DB surface seawater. Several studies have shown that $n$-alkanes from dispersed crude oils may degrade faster than many PAHs in seawater at low temperature (McFarlin et al. 2014a, b; Ribicic et al. 2018; Brakstad et al. 2018b), in agreement with the assumption that hydrocarbon degradation rates follow the order $n$-alkanes $>$ branched alkanes $>$ low molecular weight aromatics $>$ cyclic alkanes alkanes (Perry 1984).

In all seawaters, single target analyte analyses showed slower $n$-alkane biotransformation with increasing chainlength, while 2- to 4-ring PAH transformation was reduced by increasing alkyl substitution, in agreement with previous measurement (Venosa and Holder 2007; Prince et al. 2013; McFarlin et al. 2014a, b; Brakstad et al. 2015a). However, both $n$-alkane and 2- to 4-ring PAHs were degraded slower in the DB subsurface seawater than in the two other seawater sources. Recent oil biodegradation studies with subsurface seawater from DB (150 m depth), using crude oils from Oseberg Blend (100 $\mathrm{mg} \mathrm{L}^{-1} ; 5^{\circ} \mathrm{C}$ incubation temperature) or Draugen $\left(2.5-10 \mathrm{mg} \mathrm{L}^{-1} ; 2{ }^{\circ} \mathrm{C}\right.$ incubation temperature), showed that $n$-alkane biotransformation was comparable to our results. However, only $\mathrm{C}_{0^{-}}$and $\mathrm{C}_{1}$-naphthalenes showed evidence of biodegradation after 71 days of incubations, while fluorenes, dibenzothiophenes, phenanthrenes, chrysenes or pyrenes did not degrade at any measurable extent in these studies (Kristensen et al. 2015; Scheibye et al. 2017). Although PAH biotransformation in DB subsurface seawater was slow in our studies, even slower PAH transformation was therefore measured with the water from $150 \mathrm{~m}$ depth. One possible explanation for the obviously decreased PAH biotransformation by increasing water depth could be that the more stable subsurface seawater (Hansen et al. 2012) represented a more pristine environment with no previous exposure to hydrocarbon contamination. However, both, oil quality, concentration and experimental conditions probably affected the differences in the results. In agreement with our results, other biodegradation studies of oils and hydrocarbons with Arctic seawater have shown the potential for biodegradation of PAH compounds (Bagi et al. 2014; McFarlin et al. 2014b; Ribicic et al. 2018).

Biotransformation half-lives as determined for the OSCAR groups, showed differences between the oil dispersions with respect to compound group water solubilities. While water-soluble groups like $\mathrm{C}_{5}$ - to $\mathrm{C}_{8}$-saturates, benzenes and naphthalenes showed mainly comparable results between the water sources, the half-lives of the poorly soluble saturates were longer in the DB than the TRD seawaters. It must be emphasized that each oil compound group used in the OSCAR model represents individual compounds with different degradation rates, as exemplified with the different half-lives between non-alkylated and alkylated PAHs, and between $n$-alkanes and other unresolved compounds in the saturate groups, in this and other studies (Brakstad et al. 2015a; Brakstad et al. 2018a; Ribicic et al. 2018). The degradation rates will therefore be dependent largely on the quantitatively predominant compounds of each group. In a biodegradation study of a paraffinic oil (Macondo) with two oil-droplet sizes (median droplet diameters of $10 \mu \mathrm{m}$ and $30 \mu \mathrm{m}$ ), using TRD subsurface seawater and $5^{\circ} \mathrm{C}$ incubation temperature, revised half-lives of saturate and aromatic OSCAR oil compound groups ranged between 3 and 72 days, and 4-128 days, in the 10 and $30 \mu \mathrm{m}$ dispersions, respectively (Brakstad et al. 2015a). The Macondo oil halflives in the TRD subsurface seawater were mainly comparable to the Troll oil half-lives in the TRD surface seawater for the quantitatively predominant saturates $\left(\mathrm{C}_{19}-\mathrm{C}_{25}+\right.$ Sat $)$ and 3-ring PAH (PAH-1), while biotransformation rates were faster in both Macondo oil-droplet size dispersions for volatile aromatics (benzenes), smaller saturates $\left(\mathrm{C}_{10}-\mathrm{C}_{18}\right.$ Sat), naphthalenes (Naph-1 and Naph-2) and 4- to 5-ring PAH (PAH-1) (Brakstad et al. 2015a). The revised half-lives thus differed generally more between the two oils for the aromatic than the saturate groups, and these differences may be the result of different oil properties, since the Macondo oil is an highly dispersible paraffinic oil (Brakstad et al. 2014), while 
the Troll oil is a naphthenic oil. Although a recent study showed comparable biotransformation half-lives between oils with different properties when incubated in natural seawater at $13{ }^{\circ} \mathrm{C}$ (Brakstad et al. 2018a), oil compound biotransformation differences may increase with reduced temperature, partly because of differences in oil properties like viscosity, pour point and wax precipitation (Margesin and Schinner 1999). Spatial and temporal differences in seawater properties may also have influenced the different results in the TRD surface and subsurface seawater, for instance ammonium concentrations differed between the TRD seawater samples (Online Resource 6).

The comparison of experimental data and $Q_{10}$ calculations indicated that the $Q_{10}$ method overestimated biodegradation of semivolatile OSCAR groups at $5{ }^{\circ} \mathrm{C}$ when compared to experimental data, even when compared to the data from the same seawater source (Brakstad et al. 2018a). Bagi et al. (2013) performed $Q_{10}$ calculations for several oil biodegradation data sets and observed high variations in values. They concluded that, considering non-nutrient limitations (using low oil concentrations), differences in bacterial community compositions may be a key parameter (Bagi et al. 2013), but also the oil properties may become important parameters at low temperatures (Margesin and Schinner 1999).

Examination of microbial communities in the seawater sources were partly in agreement with results from previous analyses of seawater from the Western Greenland coast, with abundances of Rhodobacteraceae, Colwelliaceae, Oceanospirillaceaeae (Frette et al. 2010; Dziallas et al. 2013). Also the TRD communities were in agreement with recent data from TRD surface seawater was predominated by Rhodobacteraceae, Synechococcus and non-identified groups, in agreement with data from previous studies (Brakstad et al. 2015b). Although the TRD seawater was collected at a temperature of $11{ }^{\circ} \mathrm{C}$, we have previously detected typical psychrophilic oil-degrading bacteria in this water (Lofthus et al. 2018; Ribicic et al. 2018).

Several of the community members emerging in the dispersions during the biodegradation period are associated with oil biodegradation. Oceanospirillaceae is associated with alkane metabolism (Hazen et al. 2010; Redmond and Valentine 2012; Dubinsky et al. 2013; Brakstad et al. 2015b; Wang et al. 2016), in agreement with the abundances early during the oil biodegradation period. This family was represented by the genus Oleispira, known to biodegrade alkanes at low seawater temperatures (Yakimov et al. 2003; Coulon et al. 2007; Golyshin et al. 2010; Lofthus et al. 2018). Sulfitobacter and Polaribacter are also associated with oil biodegradation in seawater or with oil-contaminated marine environments (Deppe et al. 2005; Brakstad et al. 2008, 2018b; Guibert et al. 2012; Dubinsky et al. 2013; Ribicic et al. 2018). The changes of the microbial successions during the biodegradation period were associated with increasing abundance of bacteria able to metabolize aromatic hydrocarbons, as shown by the emergences of Cycloclasticus and Porticoccaceae. Cycloclasticus is able to transform a variety of monoaromatic hydrocarbons and PAHs in the marine environment (Geiselbrecht et al. 1998; Kasai et al. 2003; Wang et al. 2008), while members of the gammaproteobacterial family Porticoccaceae have been involved in biodegradation of PAH from oil, (Gutierrez et al. 2012). Interestingly, high abundances of Colwellia were observed in the DB subsurface seawater, a group of bacteria associated with biodegradation of a variety of hydrocarbons at low seawater temperatures (Mason et al. 2012; Redmond and Valentine 2012; Valentine et al. 2012).

\section{Conclusions}

The results from these studies showed that seawater from an Arctic environment in Western Greenland contained microbial communities with the capacity to biodegrade oil compounds in dispersed oil. When compared to a surface seawater from a temperate Norwegian fjord, using similar biodegradation temperatures, $n$-alkanes and 2- to 4-ring PAH in a dispersed naphthenic crude oil were degraded slower in the Greenland seawater, particularly in a subsurface seawater. When biodegradation rates and half-lives of 21 oil compound groups representing $70-80 \%$ of the oil were compared, both surface and subsurface Greenland seawater biodegraded the oil compound groups significantly slower than the temperate seawater at the same temperature. However, degradation of volatile and semivolatile aromatic oil compounds associated with acute effects (Faksness et al. 2015), differed less than the quantitatively predominant saturates. The Greenland and Norwegian seawater differed with respect the abundances of microbial communities, and oil compound biodegradation was associated with different bacterial groups in the seawater from the different environments. However, typical oil-degrading bacteria were present in all the seawater sources and increased in abundances during oil biodegradation. This and other studies show that hydrocarbons are biodegraded in Arctic seawater after an oil spill, but degradation rates at low temperatures may vary in seawater from different environments. These data will therefore be of importance when predicting the environmental fate and potential impacts of oil spills in the Arctic. Numerical oil spill prediction tools, like the OSCAR model, which include biodegradation as one of the processes for predicting the fate of spilled oil, may use biodegradation data from a reference temperature adjusted to the ambient temperature by a $Q_{10}$ approach. From the results of this study, it should be considered using experimental data for the relevant Arctic environment directly if available, rather 
than to temperature-calibrate data from temperate seawater environments.

Acknowledgement This project was financed by Equinor ASA under the Framework Agreement \# 4600015742 "Development of modelling tools for Environmental Risk Assessment in ice-infested sea waters". We wish to thank Marianne U. Rønsberg, Inger Kjersti Almås, Marianne Aas, Inger B. Steinsvik, Lisbet R. Støen, Kristin Bonaunet and Marianne A. Molid for their technical assistance.

\section{Compliance with ethical standards}

Conflict of interest The authors declare that they have no conflict of interest.

Open Access This article is distributed under the terms of the Creative Commons Attribution 4.0 International License (http://creativeco mmons.org/licenses/by/4.0/), which permits unrestricted use, distribution, and reproduction in any medium, provided you give appropriate credit to the original author(s) and the source, provide a link to the Creative Commons license, and indicate if changes were made.

\section{References}

Bælum J, Borglin S, Chakraborty R, Fortney JL, Lamendella R, Mason OU, Auer M, Zemla M, Bill M, Conrad ME, Malfatti SA, Tringe SG, Holman H-Y, Hazen TC, Jansson JK (2012) Deep-sea bacteria enriched by oil and dispersant from the Deepwater Horizon spill. Environ Microbiol 14:2405-2416

Bagi A, Pampanin DM, Brakstad OG, Kommedal R (2013) Estimation of hydrocarbon biodegradation rates in marine environments: a critical review of the Q10 approach. Mar Environ Res 89:83-90

Bagi A, Pampanin DM, Lanzén A, Bilstad T, Kommedal R (2014) Naphthalene biodegradation in temperate and arctic marine microcosms. Biodegradation 25:111-125

Bird KJ, Charpentier RR, Gautier DL, Houseknecht DW, Klett TR, Pitman JK, Moore TE, Schenk CJ, Tennyson ME, Wandrey CR (2008) Circum-arctic resource appraisal: estimates of undiscovered oil and gas north of the arctic circle. Fact Sheet, Version 1.0

Bowman JP, McCuaig RD (2003) Biodiversity, community structural shifts, and biogeography of prokaryotes within Antarctic continental shelf sediment. Appl Environ Microbiol 69:2463-2483

Bragg JR, Prince RC, Harner EJ, Atlas RM (1994) Effectiveness of bioremediation for the Exxon Valdez oil spill. Nature 368:413

Brakstad O, Faksness L-G (2000) Biodegradation of water-accommodated fractions and dispersed oil in the seawater column. In: SPE International Conference on Health, Safety and Environment in Oil and Gas Exploration and Production, 2000. Stavanger, Norway

Brakstad OG, Nonstad I, Faksness L-G, Brandvik PJ (2008) Responses of microbial communities in arctic sea ice after contamination by crude petroleum oil. Microb Ecol 55:540-552

Brakstad OG, Daling PS, Faksness L-G, Almås IK, Vang S-H, Syslak L, Leirvik F (2014) Depletion and biodegradation of hydrocarbons in dispersions and emulsions of the Macondo 252 oil generated in an oil-on-seawater mesocosm flume basin. Mar Pollut Bull $84: 125-134$

Brakstad OG, Nordtug T, Throne-Holst M (2015a) Biodegradation of dispersed Macondo oil in seawater at low temperature and different oil droplet sizes. Mar Pollut Bull 93:144-152

Brakstad OG, Throne-Holst M, Netzer R, Stoeckel DM, Atlas RM (2015b) Microbial communities related to biodegradation of dispersed Macondo oil at low seawater temperature with Norwegian coastal seawater. Microb Biotechnol 8:989-998

Brakstad OG, Farooq U, Ribicic D, Netzer R (2018a) Dispersibility and biotransformation of oils with different properties. Chemosphere 191:44-53

Brakstad OG, Ribicic D, Winkler A, Netzer R (2018b) Biodegradation of dispersed oil in seawater is not inhibited by a commercial oil spill dispersant. Mar Pollut Bull 129:555-561

Caporaso JG, Kuczynski J, Stombaugh J, Bittinger K, Bushman FD, Costello EK, Fierer N, Peña AG, Goodrich JK, Gordon JI (2010) QIIME allows analysis of high-throughput community sequencing data. Nat Meth 7:335-336

Coulon F, McKew BA, Osborn AM, McGenity TJ, Timmis KN (2007) Effects of temperature and biostimulation on oil-degrading microbial communities in temperate estuarine waters. Environ Microbiol 9:177-186. https://doi.org/10.1111/j.1462-2920.2006.01126

Delille D, Basseres A, Dessommes A (1998a) Effectiveness of bioremediation for oil-polluted Antarctic seawater. Polar Biol 19:237-241

Delille D, Basseres A, Dessommes A, Rosiers C (1998b) Influence of daylight on potential biodegradation of diesel and crude oil in Antarctic seawater. Mar Environ Res 45:249-258

Delille D, Pelletier E, Rodriguez-Blanco A, Ghiglione JF (2009) Effects of nutrient and temperature on degradation of petroleum hydrocarbons in sub-Antarctic coastal seawater. Polar Biol 32:1521-1528

Deppe U, Richnow H-H, Michaelis W, Antranikian G (2005) Degradation of crude oil by an arctic microbial consortium. Extremophiles 9:461-470

Dubinsky EA, Conrad ME, Chakraborty R, Bill M, Borglin SE, Hollibaugh JT, Mason OU, M. Piceno Y, Reid FC, Stringfellow WT, Tom LM, Hazen TC, Andersen GL (2013) Succession of hydrocarbon-degrading bacteria in the aftermath of the deepwater horizon oil spill in the Gulf of Mexico. Environ Sci Technol 47:10860-10867

Dziallas C, Grossart H-P, Tang KW, Nielsen TG (2013) Distinct communities of free-living and copepod-associated microorganisms along a salinity gradient in Godthåbsfjord, West Greenland. Arct Antarct Alp Res 45:471-480

Faksness L-G, Altin D, Nordtug T, Daling PS, Hansen BH (2015) Chemical comparison and acute toxicity of water accommodated fraction (WAF) of source and field collected Macondo oils from the Deepwater Horizon spill. Mar Pollut Bull 91:222-229

Frette L, Winding A, Kroer N (2010) Genetic and metabolic diversity of Arctic bacterioplankton during the post-spring phytoplankton bloom in Disko Bay, western Greenland. Aquat Microb Ecol 60:29-41

Garneau M-E, Michel C, Meisterhans G, Fortin N, King TL, Greer CW, Lee K (2016) Hydrocarbon biodegradation by Arctic sea-ice and sub-ice microbial communities during microcosm experiments, Northwest Passage (Nunavut, Canada). FEMS Microbiol Ecol 92:fiw 130

Geiselbrecht AD, Hedlund BP, Tichi MA, Staley JT (1998) Isolation of marine polycyclic aromatic hydrocarbon (PAH)-degrading Cycloclasticus strains from the Gulf of Mexico and comparison of their PAH degradation ability with that of Puget Sound Cycloclasticus strains. Appl Environ Microbiol 64:4703-4710

Gerdes B, Brinkmeyer R, Dieckmann G, Helmke E (2005) Influence of crude oil on changes of bacterial communities in Arctic sea-ice. FEMS Microbiol Ecol 53:129-139

Golyshin PN, Ferrer M, Chernikova TN, Golyshina OV, Yakimov MM (2010) Oleispira. In: Timmis K (ed) Handbook of hydrocarbon and lipid microbiology. Springer, Berlin, pp 1755-1763. https:// doi.org/10.1007/978-3-540-77587-4_125

Guibert LM, Loviso CL, Marcos MS, Commendatore MG, Dionisi HM, Lozada M (2012) Alkane biodegradation genes from 
chronically polluted subantarctic coastal sediments and their shifts in response to oil exposure. Microb Ecol 64:605-616

Gutierrez T, Nichols PD, Whitman WB, Aitken MD (2012) Porticoccus hydrocarbonoclasticus sp. nov., an aromatic hydrocarbondegrading bacterium identified in laboratory cultures of marine phytoplankton. Appl Environ Microbiol 78:628-637

Hansen MO, Nielsen TG, Stedmon CA, Munk P (2012) Oceanographic regime shift during 1997 in Disko Bay, western Greenland. Limnol Oceanogr 57(2):634-644

Hazen TC, Dubinsky EA, DeSantis TZ, Andersen GL, Piceno YM, Singh N, Jansson JK, Probst A, Borglin SE, Fortney JL, Stringfellow WT, Bill M, Conrad ME, Tom LM, Chavarria KL, Alusi TR, Lamendella R, Joyner DC, Spier C, Baelum J, Auer M, Zemla ML, Chakraborty R, Sonnenthal EL, D'haeseleer P, Holman H-YN, Osman S, Lu Z, Van Nostrand JD, Deng Y, Zhou J, Mason OU (2010) Deep-sea oil plume enriches indigenous oil-degrading bacteria. Science 330:204-208

Kasai Y, Shindo K, Harayama S, Misawa N (2003) Molecular characterization and substrate preference of a polycyclic aromatic hydrocarbon dioxygenase from Cycloclasticus sp. strain A5. Appl Environ Microbiol 69:6688-6697

Kleindienst S, Seidel M, Ziervogel K, Grim S, Loftis K, Harrison S, Malkin SY, Perkins MJ, Field J, Sogin ML, Dittmar T, Passow U, Medeiros PM, Joye SB (2015) Chemical dispersants can suppress the activity of natural oil-degrading microorganisms. Proc Nat Acad Sci 112:14900-14905

Klindworth A, Pruesse E, Schweer T, Peplies J, Quast C, Horn M, Glöckner FO (2013) Evaluation of general 16S ribosomal RNA gene PCR primers for classical and next-generation sequencingbased diversity studies. Nucl Acids Res 41:e1-e1

Kristensen M, Johnsen AR, Christensen JH (2015) Marine biodegradation of crude oil in temperate and Arctic water samples. J Hazard Mater 300:75-83

Lee K, Nedwed T, Prince RC, Palandro D (2013) Lab tests on the biodegradation of chemically dispersed oil should consider the rapid dilution that occurs at sea. Mar Pollut Bull 73:314-318

Lewis A, Prince RC (2018) Integrating dispersants in oil spill response in Arctic and other icy environments. Environ Sci Technol 52:6098-6112

Lindstrom JE, Braddock JF (2002) Biodegradation of petroleum hydrocarbons at low temperature in the presence of the dispersant Corexit 9500. Mar Pollut Bull 44:739-747

Lofthus S, Netzer R, Lewin AS, Heggeset TM, Haugen T, Brakstad OG (2018) Biodegradation of n-alkanes on oil-seawater interfaces at different temperatures and microbial communities associated with the degradation. Biodegradation 29:141-157

Macnaughton SJ, Swannell R, Daniel F, Bristow L (2003) Biodegradation of dispersed forties crude and Alaskan North Slope oils in microcosms under simulated marine conditions. Spill Sci Technol Bull 8:179-186

Margesin R, Schinner F (1999) Biological decontamination of oil spills in cold environments. J Chem Technol Biotechnol 74:381-389

Mason OU, Hazen TC, Borglin S, Chain PSG, Dubinsky EA, Fortney JL, Han J, Holman HYN, Hultman J, Lamendella R, Mackelprang R, Malfatti S, Tom LM, Tringe SG, Woyke T, Zhou JH, Rubin EM, Jansson JK (2012) Metagenome, metatranscriptome and single-cell sequencing reveal microbial response to Deepwater Horizon oil spill. ISME J 6:1715-1727. https://doi.org/10.1038/ ismej.2012.59

McFarlin K, Leigh MB, Perkins R (2014a) Biodegradation of oil and dispersed oil by Arctic marine microorganisms. In: International Oil Spill Conference Proceedings, 2014. American Petroleum Institute, vol 1, p 300317

McFarlin KM, Prince RC, Perkins R, Leigh MB (2014b) Biodegradation of dispersed oil in arctic seawater at-1 C. PLoS ONE 9:e84297
McMurdie PJ, Holmes S (2013) phyloseq: an R package for reproducible interactive analysis and graphics of microbiome census data. PLoS ONE 8(4):e61217

Nordtug T, Olsen AJ, Altin D, Meier S, Overrein I, Hansen BH, Johansen $\varnothing$ (2011) Method for generating parameterized ecotoxicity data of dispersed oil for use in environmental modelling. Mar Pollut Bull 62:2106-2113

NRC (2003) Oil in the sea III: inputs, fates, and effects. National Academies Press, Washington, DC

Olsen A-SH, Hansen AM (2014) Perceptions of public participation in impact assessment: a study of offshore oil exploration in Greenland. Impact Assess Project Apprais 32:72-80

Pasquini C, Bueno AF (2007) Characterization of petroleum using near-infrared spectroscopy: quantitative modeling for the true boiling point curve and specific gravity. Fuel 86:1927-1934

Perry JJ (1984) Microbial metabolism of cyclic alkanes. In: Atlas RM (ed) Petroleum microbiology. Macmillan publ Co, New York, pp 61-98

Prince RC (2005) The microbiology of marine oil spill bioremediation. In: Ollivier B (ed) Petroleum microbiology. American Society of Microbiology, Washington DC, pp 317-335

Prince RC, Elmendorf DL, Lute JR, Hsu CS, Haith CE, Senius JD, Dechert GJ, Douglas GS, Butler EL (1994) 17. alpha. (H)21. beta. (H)-hopane as a conserved internal marker for estimating the biodegradation of crude oil. Environ Sci Technol 28:142-145

Prince RC, McFarlin KM, Butler JD, Febbo EJ, Wang FCY, Nedwed TJ (2013) The primary biodegradation of dispersed crude oil in the sea. Chemosphere 90:521-526

Redmond MC, Valentine DL (2012) Natural gas and temperature structured a microbial community response to the Deepwater Horizon oil spill. Proc Nat Acad Sci 109:20292-20297

Reed M, Aamo OM, Daling PS (1995) Quantitative analysis of alternate oil spill response strategies using OSCAR. Spill Sci Technol Bull 2:67-74

Reed M, Daling PS, Brakstad OG, Singsaas I, Faksness L-G, Hetland B, Ekrol N (2000) OSCAR2000: a multi-component 3-dimensional oil spill contingency and response model. 23. Arctic and Marine Oilspill Program (AMOP) Technical Seminar; Vancouver, BC (Canada); 14-16 Jun 2000

Ribicic D, Netzer R, Winkler A, Brakstad OG (2018) Microbial communities in seawater from an Arctic and a temperate Norwegian fjord and their potentials for biodegradation of chemically dispersed oil at low seawater temperatures. Mar Pollut Bull 129:308-317

Scheibye K, Christensen JH, Johnsen AR (2017) Biodegradation of crude oil in Arctic subsurface water from the Disko Bay (Greenland) is limited. Environ Pollut 223:73-80

Siron R, Pelletier É, Brochu C (1995) Environmental factors influencing the biodegradation of petroleum hydrocarbons in cold seawater. Arch Environ Contam Toxicol 28:406-416

Swannell RP, Daniel F (1999) Effects of dispersants on oil biodegradation under simulated marine conditions. In: International Oil Spill Conference. American Petroleum Institute, pp 169-176

Techtmann SM, Zhuang M, Campo P, Holder E, Elk M, Hazen TC, Conmy R, Santo Domingo JW (2017) Corexit 9500 enhances oil biodegradation and changes active bacterial community structure of oil-enriched microcosms. Appl Environ Microbiol 83:e03462-03416

Valentine DL, Mezic I, Macesic S, Crnjaric-Zic N, Ivic S, Hogan PJ, Fonoberov VA, Loire S (2012) Dynamic autoinoculation and the microbial ecology of a deep water hydrocarbon irruption. PNAS 109:20286-20291. https://doi.org/10.1073/pnas.1108820109

Venosa AD, Holder EL (2007) Biodegradability of dispersed crude oil at two different temperatures. Mar Pollut Bull 54:545-553 
Wang Z, Fingas M, Blenkinsopp S, Sergy G, Landriault M, Sigouin L, Lambert P (1998) Study of the 25-year-old nipisi oil spill: persistence of oil residues and comparisons between surface and subsurface sediments. Environ Sci Technol 32:2222-2232

Wang Q, Garrity GM, Tiedje JM, Cole JR (2007) Naive Bayesian classifier for rapid assignment of rRNA sequences into the new bacterial taxonomy. Appl Environ Microbiol 73:5261-5267

Wang B, Lai Q, Cui Z, Tan T, Shao Z (2008) A pyrene-degrading consortium from deep-sea sediment of the West Pacific and its key member Cycloclasticus sp. P1. Environ Microbiol 10:1948-1963

Wang J, Sandoval K, Ding Y, Stoeckel D, Minard-Smith A, Andersen G, Dubinsky EA, Atlas R, Gardinali P (2016) Biodegradation of dispersed Macondo crude oil by indigenous Gulf of Mexico microbial communities. Sci Tot Environ 557:453-468

Yakimov MM, Giuliano L, Gentile G, Crisafi E, Chernikova TN, Abraham WR, Lunsdorf H, Timmis KN, Golyshin PN (2003) Oleispira antarctica gen. nov., sp nov., a novel hydrocarbonoclastic marine bacterium isolated from Antarctic coastal sea water. Int J Syst Evol Microbiol 53:779-785. https://doi.org/10.1099/ijs.0.02366-0 Yakimov MM, Gentile G, Bruni V, Cappello S, D’Auria G, Golyshin PN, Giuliano L (2004) Crude oil-induced structural shift of coastal bacterial communities of rod bay (Terra Nova Bay, Ross Sea, Antarctica) and characterization of cultured cold-adapted hydrocarbonoclastic bacteria. FEMS Microbiol Ecol 49:419-432 